\title{
Uma vida, uma construção de todas as experiências na família, na sociedade e no trabalho Biografia da Senhora Enfermeira Professora Nídia Salgueiro
}

A life, a making of all experiences within the family, the society and at work Biography of Nurse and Professor Nídia Salgueiro

Una vida, una realización de todas las experiencias en la familia, en la sociedad y en el trabajo Biografía de la Enfermera y Profesora Nídia Salgueiro

Isabel Maria Ribeiro Fernandes*; Manuel Alves Rodrigues**

\section{Resumo}

Diz-se que não se envelhece enquanto buscamos. Esta é biografia de alguém que não tem tido tempo para o tédio e empreende cada dia da sua vida com criatividade e sabedoria. Na descrição, percorre-se a distância, da criança feliz imaginativa à mulher adulta realizadora, realçando o seu perfil humano, de curiosidade, gosto por aprender, determinação e empreendedorismo. Demonstrou de forma elevada o zelo pelos cuidados e o envolvimento no progresso da docência e da investigação em enfermagem. Hoje continua ativa no alívio do sofrimento dos outros e no impulso dos cuidados de bumanitude. É indiscutivelmente uma figura cimeira da história da enfermagem portuguesa, reconhecida pelos seus pares e por várias entidades oficiais, nacionais e estrangeiras.

\section{Abstract}

It is said that we do not grow old as long as we seek in life. This is the biography of someone whe has not had time for tedium/boredom and who plans everyday of her life with creativity and learning. In the description, we travel through the distance from a happy and imagnative childhood to adulthood as an achieving mother, realizing her human potential through curiosity, a taste for learning, and with determination and fulfillment. She demonstrates at a high level her zeal for caring and involvement in the progress of teaching and research in nursing.Today she continues to be active in the relief of the suffering of others and in her impulse to care for humanity. She is unquestionably an iconic figure in the history of Portuguese nursing, and is recognised by her peers and by various national and foreign official entities.

\footnotetext{
* Doutora em Enfermagem. Enfermeira, IPO, Coimbra [isabelfernandes76 @ gmail.com].

** Professor Coordenador Principal. PhD. Agregação, Esenfc [demar7@
} gmail.com].

\section{Resumen}

Se dice que mientras buscamos, no se envejece. Esta es la biografía de alguien que no ha tenido tiempo para el tedio y que emprende cada día de su vida con creatividad y sabiduría. En la descripción, se persigue la distancia, de la niña feliz imaginativa a la mujer adulta realizadora, realzando su perfil humano, de curiosidad, gusto por aprender, determinación y emprendimiento. Demostró intensamente el celo por los cuidados y la implicación en el progreso de docencia e investigación en enfermería. Hoy, continua activa en el ámbito del alivio del sufrimiento ajeno y del impulso de los cuidados humanitarios. Es, sin duda, una figura cumbre de la historia de la enfermería portuguesa, reconocida por sus iguales y por varias entidades oficiales, nacionales y extranjeras.

Recebido para publicação em: 12.01 .13

Aceite para publicação em: 23.06.13 


\section{Abertura}

Nascida e criada numa terra em que se sabia partilhar e agradecer - Vila Seca, concelho de Condeixaa-Nova, distrito de Coimbra, terra onde a beleza da natureza lhe inspirou sentimentos de alegria e liberdade e que a fez sentir como uma «gazela à solta». Esta oportunidade de crescer e viver em liberdade, cercada pelas mais belas serras, flores, cores e aromas, associado aos seus ritmos e energias naturais, revelouse uma experiência única e enriquecedora. Hoje considera uma bênção não ter continuado os estudos após a instrução primária, o que na altura lhe custou. Considera-se uma mulher bastante trabalhadora, hábito que lhe foi incutido desde pequenina. Perfilhou muito bem o valor do trabalho que caracterizava a sua família. $\mathrm{O}$ «ser enfermeira» marcou a sua vida, na medida em que exige o estar com o outro, lidar com o seu sofrimento e, inerentemente, o desenvolvimento de sentimentos de compaixão, amor e gratidão.

Humilde por natureza, não se deixou deslumbrar pelo poder dos cargos que exerceu, quer como Enfermeira Chefe no Hospital, quer como docente na Escola, estando agradecida por todas as experiências vividas e pelo conhecimento que lhe facultaram.

Foi e continua a ser citada como uma Senhora Enfermeira dedicada que sempre prezou pela dignificação da enfermagem. Pela profissão fez e continua a fazer tudo o que pode e está ao seu alcance, tendo em conta as suas capacidades, potencialidades e todos os recursos disponíveis nos diferentes contextos profissionais que atravessou.

Foi com entusiasmo e grande expectativa que entrevistámos a Sr. ${ }^{a}$ Enfa . Nídia (Fig. 1), com o objetivo de colocar em relevo os traços de caráter, recortes de experiências de vida, realizações importantes que permitem ver a pessoa com um percurso marcante e socialmente relevante.

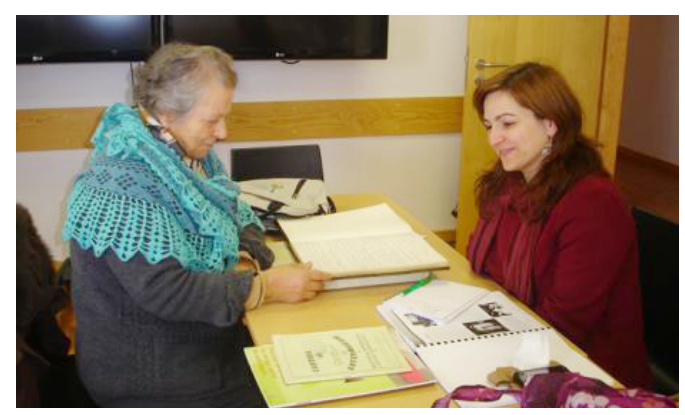

FIGURA 1 - Momento da entrevista

\section{O nascimento}

Nídia Rodrigues Mendes Salgueiro nasce a 25 de abril de 1934, fruto de um grande amor. É a filha sobrevivente de uma gravidez gemelar, tendo o parto sido muito difícil e de grande sofrimento para a sua mãe. Com a vitalidade e energia que a caracterizam não é espanto pensar que estes atributos surgiram muito cedo na sua vida, pois como refere nasceu tão depressa que até «caiu no penico». O parto da sua gémea arrastou-se, acabando em fórceps e na sua morte. Foi a primeira neta da família e, como tal, muito acarinhada por todos, falando com especial carinho do seu avô materno - Sr. Rodrigues.

As suas origens maternas são singelas, o seu avô era oriundo do Folhadal - Nelas e a sua avó de Vila Seca, de poucas posses financeiras. Recorda a inteligência do seu avô, a sua capacidade de organização e empreendedorismo. Entrou na Direção Geral de Estradas, como cantoneiro as suas capacidades rapidamente foram reconhecidas, passou a cabo de cantoneiros e quando faleceu era fiscal da Direção Geral de Estradas. Com o seu ordenado e a sábia administração da sua avó, conseguiu uma boa casa de lavoura, fazendo das terras abandonadas que foi comprando, autênticos jardins de fruteiras, oliveiras, videiras, já nesse tempo além das de vinho, também belas latadas de uvas de mesa. À avó, sempre ouviu a frase, em jeito de recomendação, «O homem a trazer para casa com um rodo não equilibra o que a mulher deita fora com 0 fundo da agulha» (o dito era cu da agulha).

A sua família paterna do Reguengo do Fetal, Batalha, pertencia a um grupo social diferente, considerado de elite, na época, vivendo numa casa senhorial, onde passou muito tempo dos seus primeiros anos de vida. Mantinham boas relações sociais.

As mulheres da sua família sempre foram muito lutadoras e as do lado paterno muito prendadas nas artes femininas: costura, bordados, confeitaria de doces conventuais e bolos típicos. Estas habilidades permitiram-lhes, quando as condições se tornaram adversas, o sustento da sua família. Uma das tias, que sozinha criou quatro filhos, dizia: «Quem sabe usar as suas mãos nunca passará fome».

\section{A criança feliz e criativa (Fig. 2)}

A sua mãe sempre foi extremamente cuidadosa com a sua alimentação e vestuário. O seu pai era o centro das suas atenções. Andavam sempre juntos, não faziam nada um sem o outro, de modo que o 
tempo disponível para os filhos era pouco. Diz, com alguma tristeza, que não recorda os gestos de carinho da sua mãe e isto, para si é um enigma, pois era uma mulher muito amorosa, pondo as necessidades dos outros sempre à frente das suas. A explicação poderá ser: havia sempre um bebé a cuidar, as preocupações com os trabalhos domésticos, a orientação dos trabalhos agrícolas à medida que foram adquirindo terras abandonadas e as transformando em vinhas, o acompanhamento do seu avô na sua doença, cuidando dele no seu trajeto doloroso, dia e noite, quando os outros se afastaram, devido ao mal-estar que lhes provocava o seu estado e o cheiro das suas lesões cancerosas.

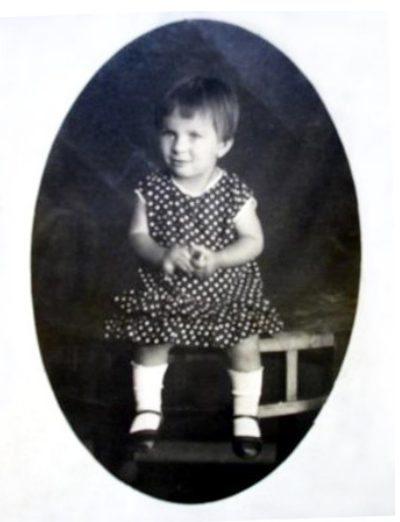

FIGURA 2 - Foto de infância

Na sua meninice, passou grandes períodos de tempo na companhia da sua avó e das três tias no Reguengo do Fetal, sendo muito feliz. Recorda os belos serões com aquelas quatro prendadas mulheres, em que tudo se aproveitava e reaproveitava (tecidos), resultando em bonitas almofadas, coberturas, tapetes, sacas e saquinhas... igualmente os coloridos bordados e outras artes manuais. A avó faleceu, as tias casaram, mas os laços não se perderam e de vez em quando passava uns tempos ora na casa de uma, ora na casa de outra, mas sempre com as três. Estas formas de estar inculcadas em criança foram determinantes na sua vida. Integrou-as e adquiriu o gosto de aproveitar e reaproveitar diversos materiais, elaborando peças que distribui pelos familiares e amigos.

O fascínio pelas flores sempre a acompanhou, sobretudo pelas flores do campo, pela sua beleza, cor e vibração. Muitas vezes era incumbida da tarefa de ir às compras e ficava "pasmada» a contemplar a beleza das flores. Recorda com saudade a Festa de $5 .{ }^{\mathrm{a}}$ Feira da Ascensão, com as flores de giesta e pétalas de rosa a caírem do coro alto e dos altares, uma pomba ou uns passaritos a esvoaçar pela igreja de S. Pedro de Vila Seca e, de tarde, o ritual de virem visitar os museus a Coimbra. Do Reguengo do Fetal, quando passava lá o "dia da espiga", ia com as tias e outras raparigas, ao campo colher a espiga, um raminho de oliveira e flores para compor o ramo que se guardava por se considerar "bento" e recorda: a Festa do Pão ou Festa do Espírito Santo em que se distribuía pão por toda a gente; a Festa dos Caracóis com as janelas e portas emolduradas com argila e onde eram colocados caracóis grandes com azeite, que se iluminavam; a arrematação das fogaças constituídas por cavacas e bolos de ferradura, entre outras iguarias, festas que perduram até ao presente. Dos moinhos e moleiros existentes na montanha, onde hoje há geradores eólicos, recorda a aprendizagem da cozedura do pão, o cheiro do arrobe, em que a meio da confeção a avó juntava camueses (peros), que, na cozedura, libertavam intenso aroma, e os da natureza, que a marcaram, sendo sensações que perduram.

Considera-se uma afortunada por ter sido criada como uma "gazela à solta», podendo explorar o meio ambiente que a rodeava e estabelecer uma relação de proximidade com a terra, rodeada de afetos, considerando a sua infância muito feliz.

\section{Amadurecimento prematuro... o primado do trabalho... e brincar fica onde?}

Começou a trabalhar muito cedo. A sua mãe, apesar de não a ensinar a fazer as coisas de acordo com as regras existentes então, tal como via outras mães fazerem com as suas filhas, sempre a incentivou a fazer de tudo. Nas lides domésticas, para a sua mãe extremamente despachada, teria sempre de demorar menos tempo, revelando algum descontentamento, embora não tecendo críticas destrutivas. Não frequentando o ensino das Mestres de costura, desde cedo fazia roupas para as crianças e nisso tem muito que lhe agradecer, pois se a peça saía mais pequena ou maior que o devido, vendo-a apreensiva, dizia-lhe «não tem importância, fica para... a mais nova ou mais velha». Entre quatro meninas, à época, havia sempre a quem servir. Sem dúvida que em casa adquiriu o sentido de autodidatismo, que perdura até hoje.

Iniciou o seu percurso escolar tarde, pois fez 7 anos em abril e só inicia a escola em outubro. A sua professora deixou as alunas da primeira classe completamente à deriva. Estava a viver um luto muito doloroso 
(falecimento do marido e dum bebé). A imagem que tem dela é de uma mulher muito franzina, sentada à secretária, vestida de preto com um chapéu, tipo queijo, do qual pendia um véu que lhe cobria o rosto, razão porque não tem qualquer imagem deste. A sala estava equipada com as tradicionais carteiras, com tinteiros, mas ela e as outras meninas suas colegas sentavam-se em bancos corridos baixos, com a particularidade do encosto virar para a frente e fazer de mesa de trabalho. Ocupavam as últimas filas. De vez em quando vinha uma aluna da $4 .{ }^{\mathrm{a}}$ classe passarlhes umas letras para fazerem e os números. Foi um ano completamente desperdiçado. Não passou de classe e as poucas colegas que passaram, cuja família procurou suprir o que na escola não tinham, ficaram sempre coxas, no dizer das professoras seguintes. Teve a sorte de a professora ser substituída no ano seguinte por outra, ativa, dinâmica e perspicaz na avaliação do saber e das capacidades das alunas. Enviou um recado aos seus pais para que viessem à escola falar com ela. Foi uma tia materna em sua representação que lhes transmitiu a deplorável situação em que se encontrava na sua aprendizagem.

À noite, o seu pai confrontou-a com o seu saber, constatando o pouco que sabia. Irritado, deu-lhe uma bofetada que a fez ficar com o «olho à belenenses» e dar uma pirueta pelo ar. No dia seguinte, a professora, colocando-lhe a mão no ombro, tranquilizou-a, dizendo-lhe que ainda "um dia iria agradecer aquela bofetada".

Não entende o que se passou, pois em pouco tempo estava na primeira adiantada e não se recorda de ter feito esforço que justificasse tal sucesso. Na $3{ }^{a}$. classe, nova professora, mas não afetou a sua aprendizagem: não dava erros, fazia muito boas redações e era imbatível na solução dos problemas de aritmética. Não se lembra de ter apanhado uma reguada, uma reprimenda na Escola. E nesse tempo a «menina de cinco olhos» (palmatória), funcionava forte e feio!

Este foi mais um enigma na sua vida. Mais tarde falando disso a professores, disseram: "há crianças que abrem mais tarde".

Não sabe «se abriu mais tarde», se foram os métodos pedagógicos da professora que soube tocar a tecla certa, se a bofetada da mão pesada do pai, que nunca agradeceu, ou se tudo em conjunto, em vez de um ano sem qualquer projeto pedagógico, duma professora em situação difícil, sem ânimo até para sair de trás da secretária, um ano «cabriolice».
Terminou a quarta classe com distinção, tendo sido a única no concelho de Condeixa- a-Nova, nesse ano, demonstrando grandes capacidades, a ponto de ouvir na rua comentários elogiosos sobre si e os seus professores a intercederem junto dos seus pais para que continuasse os estudos. Como a Professora foi Mãe e teve uns problemas de saúde, as meninas da $4 .{ }^{a}$ classe passaram para o professor, seu marido, julga que esta transferência não era oficial. Era um homem duro, que «abusava da palmatória», mas refere «nunca ter levado uma reguada na escola!». Devido à transferência para a classe dos rapazes não fizeram bordados na escola e, sendo que no exame era de tradição terminar o trabalho do ano escolar, a professora informou o júri que delineou a estratégia de as alunas iniciarem um trabalho. Nas vésperas reuniu as alunas, informou-as da estratégia, passou-lhes um desenho num pequeno "naperom", deu-lhes umas noções dos pontos a utilizar e ficaram por sua conta. Ainda hoje quando vê justificar «algum desenrasca», refere «lá está a estratégia da D. Virgínia!». O professor a par da sua dureza tinha aspetos que muito admirava: ao sábado, com todas as crianças a participar, tratavam do jardim e das plantas que rodeavam a sala de aula, pelo que o jardim dos rapazes estava sempre muito bem cuidado e as plantas muito bonitas e saudáveis, ao contrário do das meninas em absoluto desmazelo e na sala nem uma única planta; organizava concursos de desenhos, podendo estes serem Desenhos à Vista ou Desenhos de Imaginação. Estes desenhos eram avaliados e votados por todos e os mais votados ficavam expostos na sala de aula. Um princípio democrático. Os seus figuraram nesta exposição.

O seu gosto pelo desenho e as suas potencialidades não foram devidamente explorados. Um dia, já estando a trabalhar junto do seu pai, ao elaborar as listas dos trabalhadores para o seguro, teve um problema em relação aos britadores e decidiu fazer um desenho (um boneca colorida), aproveitando que os pais se tinham ausentado para resolverem um assunto. O tempo passou tão depressa que, quando eles regressaram, foi obrigada a esconder o desenho, debaixo do mata-borrão. A mãe descobriu o desenho e denunciou-a. Estava justificado o problema e o facto de não ter terminado as listas, o que conduziu a um episódio menos agradável, traduzido por uma bofetada do seu pai. Sentiu-se castrada nesta sua capacidade e fascínio pelo desenho e utilização das cores. Mesmo assim continuou a desenvolver as suas 
potencialidades, elaborando desenhos e utilizando a cor nos seus bordados.

Conclui a $4^{a}$ Classe a um sábado e na segunda-feira seguinte inicia outras funções junto do seu pai, sendo da sua responsabilidade fazer a escrita relativa aos trabalhadores, ao trabalho efetuado pelo pai com a camioneta, assumir as funções de capataz, controlo do trabalho dos britadores, os trabalhos domésticos semana sim, semana não, alternando com a mãe. $\mathrm{Na}$ semana que ia a mãe ficava ela com as crianças em Vila Seca. A mãe levava o bebé.

Saíram de casa de madrugada, na camioneta de carga do pai. Ao chegar ao Carriço foi acompanhada a casa pelo ajudante do pai. Jamais esquece o momento em que ficou sozinha naquela casa, um misto de encantamento e de incerteza. Os raios de sol acabados de nascer, filtrados pelo verde dos altos milheirais (como não havia na sua terra seca no nome e no terreno) que a cercavam, mais além o verde dos pinhais.

Depois de explorar o sítio, sentou-se na soleira da porta continuando o bordado, que tinha iniciado no sábado. Passaram duas simpáticas raparigas, a Emília e a Luísa, que a cumprimentaram, dizendo a confirmar a informação que já tinham "É a menina do Sr. Mendes!". Foi um bálsamo, sentiu que lhe davam as boas-vindas e que não estava sozinha naquela terra desconhecida. Reparou nas suas vestes, que depois confirmou serem as habituais das raparigas e mulheres locais, uma saia preta aos gomos, avental, blusa clara, na cabeça um lenço preto, com as pontas atadas por baixo do queixo, coberto por um chapéu de palha de abas largas, para se protegerem do sol enquanto trabalhavam no campo e manterem a pele do rosto clara e fresca. Eram mulheres de muito trabalho, sempre acompanhadas da enxada. Iam regar. Na volta do campo traziam, no avental, feijão-verde. "Tome para o jantar". Este gesto mais que a dádiva material simbolizou o acolhimento, uma dádiva de amor, que para si não tinha outro preço senão a amizade e o estabelecimento de uma ligação com as pessoas da terra e até a sua colaboração, quando podia, no trabalho do campo.

Tinha então 12 anos de idade, elaborou um plano diário e semanal de atividades, com uma tabela horária onde distribuiu tudo o que tinha para fazer em cada dia e atividades especiais em determinados dias. Incluía também um horário para brincar, especificamente das 15 às 16 horas. 0 plano estava afixado na porta do seu quarto, por dentro, e era cumprido à risca. A mãe descobriu-o, não sabendo ler, levou-o ao pai. Brincar como e com quem?

Naqueles tempos difíceis, no Carriço, as mães levavam consigo as crianças mais crescidas para o campo e as mais pequenas ficavam em casa fechadas à chave. Recorda o sofrimento que lhe causava o choro das crianças, às vezes com a cabecita na soleira da porta, encostada à gateira (buraco por onde entrava e saía o gato). Partia-lhe o coração não lhes poder valer. Por vezes, também ela chorava. Não tardou que a mãe descobrisse o «corpo de delito», como lhe chamou, um trapézio ou baloiço, constituído por duas cordas e um pau duro, suspenso nos fortes barrotes do alpendre, que depois de 30 minutos de exercícios acrobáticos, guardava no espaço entre os barrotes e as telhas. Denunciou-a ao pai e acabaram-se aqueles momentos de lazer e de agradável sensação de liberdade. Foi criticada toda a vida por ter escrito aquilo. Já depois de adulta e de ser mãe, quando mais uma vez foi lembrado «15 às $16 \mathrm{H}$ brincar» questionou os seus pais acerca da legitimidade de uma criança ter tempo para brincar e fez-lhes o reparo de nunca lhe falarem nas outras atividades inscritas naquele plano. Ainda hoje recorda a sensação de frio nas mãos, resultante da água gelada onde ia lavar a roupa à mão e questiona-se como conseguia lavar as jardineiras de forte ganga do seu pai. Apesar de não ter tido tempo para brincar e de não fazer coisas de que gostaria, considera que a sua aprendizagem foi muito útil e não se lamenta.

\section{$O$ gosto de ensinar e a determinaçáo em aprender «...mal sabia para si e já ensinava os outros!»}

A sua mãe apenas lhe ensinou a fazer o básico de renda, cordão e abertos e fechados. No Carriço havia duas costureiras, as «Marias Mancas», que devido a osteítes ou paralisias infantis eram poupadas aos trabalhos duros. Uma delas, além da costura, fazia renda muito bem e ensinava as suas aprendizas a fazer. A Nídia gostou de uma amostra, tendo solicitado que a ensinasse. A senhora não a ensinou, mas emprestou-lhe a amostra, dizendo-lhe que teria de a devolver no dia seguinte. A renda tinha um segredo, com a sua persistência e não se deixando desmoralizar, em casa pacientemente, à luz do candeeiro de petróleo, decifrou-o. No dia seguinte foi devolver a amostra, como havia sido combinado e a 
Mestre disse «Conseguiu?», ficando perplexa quando lhe exibiu o que tinha feito. Só então percebeu que o empréstimo da amostra não foi de boa-fé. Talvez «temesse a concorrência!». A outra, menos preparada, dava-se mais a remendar roupas, a confecionar roupas simples para as pessoas simples. Mostrou desejo de aprender a fazer renda e eis a Nídia, que nas suas palavras «não sabia para ela», a ensiná-la e com isso a aprender também.

Ao longo deste período de trabalho junto do seu pai aprendeu e desenvolveu-se muito como pessoa ao relacionar-se com muita gente. Estava-se no pósguerra, havia dificuldade em obter alguns alimentos; os britadores de Semide, contratados pelo seu pai para partir o filão granítico de Monte Redondo, pedra difícil e com uma forma própria de partir, só aceitaram na condição de o seu pai lhes arranjar broa, que era feita por uma senhora da aldeia, e que a Nídia pesava e dividia por todos eles, de forma igualitária, fomentando o sentido de justiça.

Passou também por fases difíceis, nomeadamente no relacionamento com o seu pai, que passava um período muito conturbado, devido à descoberta das «falcatruas» (dívidas) cometidas pelo seu sócio, em que o dinheiro do financiador foi sendo gasto mas a obra estava longe de estar concluída. O pai, homem para quem os compromissos eram para cumprir, trabalhava sem descanso e fazia-a trabalhar, não comia ou comia muito mal, quase não falava, sempre mal-humorado, com ideias destrutivas. Muitas vezes, tinha de lhe levar o almoço a 3 e 5 Km de distância para, no momento, não comer. Instada pela mãe fazia-lhe uns mimos da sua predileção, diferente do que fazia para ela e o ajudante, o Ramiro. Nem the tocava. O Ramiro tinha muito jeito para lidar com o patrão. "Então não come, assim a rapariga nem sabe se está bom! Vamos comê-lo nós!". Acabava por ser ele a comer o acepipe, sozinho. "Estás aprovada, podes continuar!". E ria-se, mas o Sr. Mendes continuava sisudo. A Nídia acabava por não comer, ficando muito debilitada e com problemas intestinais, valendo-lhe as tias paternas. Foi ao Reguengo para ser Madrinha duma prima, com a condição de voltar após o batizado. As tias ao verem o seu estado insurgiramse com o irmão e ficou lá três meses, um em casa de cada tia. Quando regressou estava irreconhecível: uma bela moçoila de cores saudáveis, o oposto da enfezada e amarelenta que tinha ido.

O seu pai sempre foi um homem observador, com sentido de atribuição de responsabilidades e capacidade de estimular a autoconfiança nos outros. Libertou-se do sócio, conseguindo pelo seu esforço,motivo de orgulho, que o financiador não saísse prejudicado, mas não aceitou a sua proposta de sociedade. Dizia que tinha ficado vacinado de sociedades. Pelas contingências da altura, viu-se obrigado a mudar de ramo de trabalho, passando a fornecer lenha para alimentar as fornalhas de aquecimento de algumas instituições, em que ganhou os concursos (HUC, Penitenciária...). Por isso se fez madeireiro. Necessitava de colaboração de um rapaz para lhe tratar dos assuntos burocráticos e decidiu que a filha tinha de aprender a andar de bicicleta. A um domingo ensinou-lhe os princípios básicos para utilizar a bicicleta, na sua roda 26. Largou-a numa pequena descida, a bicicleta ganhou velocidade e quando se apercebeu que ia sozinha e não era capaz de desmontar, meteu-se na valeta, fazendose tombar, por azar rompeu a câmara-de-ar; nada que não se resolvesse com um remendo. Treinou sozinha o resto do domingo e, no dia seguinte, o pai mandou-a à Câmara Municipal de Condeixa, tratar de assuntos importantes, passando, daí em diante, a assumir funções deste tipo, como pagar os impostos, entregar propostas, receber e pagar faturas, depositar dinheiros, etc. Também the foi incumbida a missão de comprar madeira, exigindo uma análise cuidadosa em termos de diâmetro dos toros, se davam para madeira ou só para lenha, por serem tortos ou apresentarem muitas cicatrizes da resinagem, etc. O preço era feito em função desta avaliação. Apesar de admitir que possa ter cometido erros nas suas avaliações nunca foi criticada por isso.

Tinha de levar na sua bicicleta um pipo de vinho para os lenhadores, o dinheiro numa «saquita» embrulhada no guiador, um serrote e a sua comida. O seu espírito de partilha desde cedo se revelou, pois dava o seu «conduto» a uma família pobre, moradora numa casita, junto ao seu posto de compra de madeira, comendo a sua sopa, facto que escandalizou a mãe quando se apercebeu da sopa que aquela família comia. Por outro lado ensinava a sua filha, a Lúcia, a ler, uma vez que os pais não a deixaram ir à Escola, em resultado de um caso amoroso passado na aldeia, com fuga de uma jovem com o namorado, que envolveu troca de cartas. A partir daí, as famílias não deixavam ir as filhas à Escola. Passou a ser pastora, mas ávida de aprender, rapidamente conseguiu ler e iniciar-se na escrita, com a sua ajuda. Entretanto, a Nídia foi admitida no Curso 
de Pré-Enfermagem, tendo vindo para Coimbra e perdeu o contacto com ela. Qual não é o seu espanto quando, já a frequentar o Curso de Enfermagem Geral (CEG) recebe uma carta da Lúcia, informando-a que estava a trabalhar em Lisboa e a expressão da sua gratidão.

\section{Da descoberta da escola de enfermagem ao ser enfermeira "....Nada acontece por acaso...."}

As suas memórias acerca de hospitais e seus profissionais eram muito diminutas e carregadas de emoções pouco agradáveis, nomeadamente quando visitou o seu avô no Hospital da Universidade, retendo o forte impacto do cheiro intenso a creolina e aos desinfetantes, que ficou bem gravado na sua memória. Por outro lado, o facto de o seu avô padecer de um cancro na cavidade bucal, com necessidade de realização de pensos frequentes fez com que tivesse estabelecido algum contacto, ténue e pouco vinculativo com a enfermagem, através do Senhor Enfermeiro Alves, que trabalhava em regime particular, por avença, visitando os doentes no seu domicílio. No caso vinha fazer os pensos, deslocando-se de égua (tem a imagem muito nítida do local onde era preso o animal, enquanto o Sr. Alves cuidava do avô). Sempre pensou que era um cavalo branco, até há poucos anos em que contactando o seu filho octogenário, para saber se tinha documentos fotográficos e outros do seu pai, este lhe diz que era uma égua.

A escolha da profissão de enfermagem não se deveu a nenhum chamamento interior. Aconteceu casualmente na sua vida. Num dos seus passeios, sentada no meio das flores silvestres, deu consigo a pensar "O que vou fazer?!". Esta dúvida e incerteza resultavam, em parte, de não considerar a costura a área certa para si e de constatar que não era viável fazer o curso de professora. Não via saída para o que desejava para a sua vida, que passava por continuar a estudar e fazer um curso. Nesse mesmo dia o pai, que fornecia lenha para os Hospitais da Universidade de Coimbra, disse-lhe que tinha tido conhecimento de que estavam abertas inscrições para um curso de preparação para a entrada no Curso de Enfermagem e se estava interessada. Claro que estava. O pai ofereceuse para a acompanhar à Escola. Para seu espanto e desilusão tomou conhecimento de que as inscrições já estavam encerradas, mas que poderia inscrever-se, desde que pagasse a multa. O pai prontificou-se de imediato a pagar o que fosse preciso e, na Secretaria, a fazerem a inscrição condicional até que entregasse todos os documentos exigidos. O tempo que mediou entre a inscrição e os exames de admissão foi gasto na azáfama da obtenção dos documentos necessários: certidões de nascimento e de habilitações, de bom comportamento passadas pela junta de freguesia, de aprumo moral passado pelo pároco, ficando para trás a preparação para o exame de admissão.

No momento da realização do exame ficou ao lado da candidata Zulmilda que estava sempre a solicitar a sua ajuda em questões de matemática, o que lhe perturbou a sua atenção e concentração. Errou contas. Aquando da divulgação da classificação, deparou-se com a surpresa de a jovem perturbadora estar em $30^{\circ}$ lugar e a Nídia em $31^{\circ}$, na lista classificativa. Ora, como só havia 30 vagas ficaria excluída, tendo vivido a segunda grande desilusão. Na Secretaria, sugeriramlhe que deixasse o contacto telefónico, para a eventualidade de haver alguma desistência. Assim fez, mas sem grande esperança. Inesperadamente ao fim de um mês é contactada, sendo informada que tinha havido uma desistência, justamente a Zulmilda, para se apresentar, caso continuasse interessada. Inicia-se, então, uma nova etapa da sua vida, vindo viver para Coimbra, na casa do seu tio-avô, onde foi muito bem acolhida. Tinha à data 16 anos de idade.

Tendo em conta que já haviam iniciado as aulas há um mês, teve que desenvolver um esforço acrescido para conseguir pôr-se a par dos conteúdos já lecionados e acompanhar as aulas. Constatou que o sentido da partilha não estava muito presente nos colegas ou pela sua própria necessidade de estudo, pois não the facultavam os apontamentos das várias disciplinas. A professora de francês, D. Odília Freitas, informou-a de que já tinha dado a fonética e na gramática já iam na conjugação dos verbos irregulares "avoir e être", não podia voltar atrás, tinha que se pôr a par. Como lhe é característico, colocou mãos à obra, adquiriu uma gramática de francês na Coimbra Editora, que foi essencial para se pôr a par e acompanhar a progressão da disciplina.

Recorda que na aula seguinte de francês, na "Sala do Esqueleto", a D. Odília, que tinha um método pedagógico fantástico: revisão da matéria dada, com exercícios de aplicação, matéria nova, exercícios de aplicação e passagem de exercícios para casa. Talvez para testar se tinha tomado a peito as suas recomendações pediu à nova aluna para conjugar 
o presente do indicativo dos dois verbos acima referidos. De imediato conjugou os dois verbos, mas pronunciados à portuguesa. Risada da turma. "Anda cá, escreve no quadro". A escrita foi correta. Pôs-lhe a mão no ombro, e viradas para a turma, felicitou-a, dizendo aos trocistas que se chamasse alguns deles ao quadro tinha dúvidas que tivessem aquele desempenho. Era a segunda professora a pôr-lhe a mão no ombro frente à turma, por razões diferentes. O incentivo foi tão profícuo que, no segundo ano, a pedido da professora, dava explicações aos colegas do primeiro ano que apresentavam maiores dificuldades, traduzindo o que pensava dela própria «Mal sabia para si ejá ensinava os outros».Dos trinta estudantes iniciais apenas seis (Fig. 3) passaram para o segundo ano e concluíram o curso, relacionando-se como irmãos e entreajudando-se. Faziam do Jardim Botânico a sua sala de estudo. A Nídia obteve a classificação de 17 valores, I prémio da Escola, e, no exame de Admissão ao $\mathrm{CEG}$, em que competiam com os que vinham de fora, todos foram aprovados e admitidos, ela foi a primeira na lista classificativa dos candidatos, a "Menina dos três vintes!" como lhe chamavam. Destes seis, um colega, após os exames do segundo ano, com bom aproveitamento, respondeu ao chamado para a tropa, e ingressou na carreira militar; uma colega depois do CEG continuou os estudos e fez uma licenciatura em letras, seguindo a carreira de professora do ensino liceal; os restantes, três mulheres e um homem, mantiveram-se na profissão de enfermagem, com carreiras bem-sucedidas. Os fortes laços entre os cinco que terminaram o CEG não se perderam. A que seguiu a carreira do ensino liceal tem estado sempre presente nos momentos importantes como as comemorações dos 25 e 50 anos de Curso e outros. O militar, perderam-lhe completamente o rasto, embora fizessem esforços para o reencontrar.

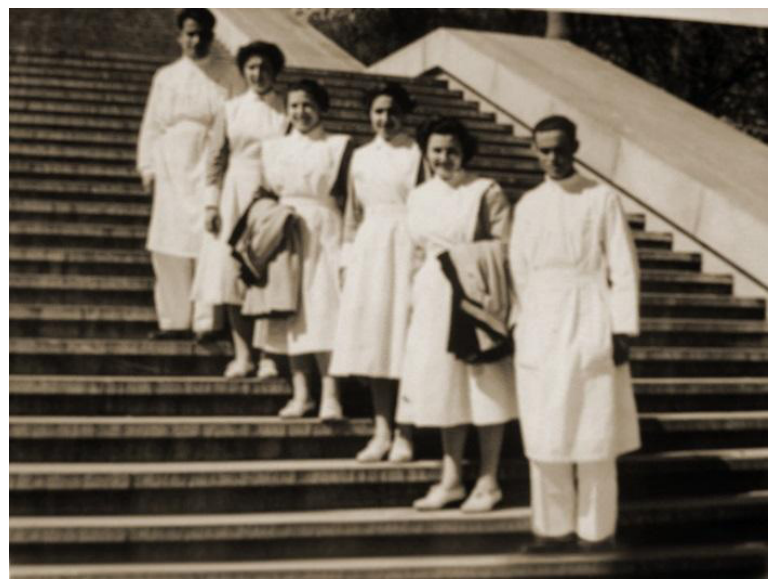

FIGURA 3 - Os seis estudantes que concluíram o curso de pré-enfermagem e já no $1^{\circ}$ ano do CEG (1952).

Terminou o CEG em 1955, com a classificação de Muito Bom, 16 valores e o Curso Enfermagem Complementar (CEC), em 1957, com a classificação de Bom, 15 valores em ambas as secções, Ensino e Administração. Considera um ótimo resultado, atendendo a que o obteve a trabalhar. Concluiu também nesse ano uma das secções do $2{ }^{\circ}$ ciclo liceal e desempenhou nos Hospitais da Universidade de Coimbra (HUC) funções muito exigentes, como 31 noites (mês de março), sem qualquer folga pelo meio, em três serviços, Pediatria, Cardiologia e Terapêutica Médica (3. $\left.{ }^{\mathrm{a}} \mathrm{MM}\right)$, além de ser submetida a uma intervenção cirúrgica no IPO de Lisboa a um olho. Em 1983, ingressa no Curso de Especialização em Enfermagem Médico-Cirúrgica, que termina em 1984 com a classificação de Muito Bom (16 valores). Toda a sua formação foi realizada na Escola de Enfermagem Dr. Ângelo da Fonseca (EEAF). Em 1991, é-lhe atribuída a equivalência ao diploma de Estudos Superiores Especializados em Enfermagem, correspondendo ao grau de licenciatura, ao abrigo do Despacho Ministerial $\mathrm{n}^{\circ} 4$, tendo por base 0 artigo $10^{\circ}$ do Decreto-Lei $n^{0}$ 480/1988, alterado pelo DecretoLei $n^{0} 100$ de 1990, relativo à Integração do Ensino de Enfermagem no Ensino Superior. Posteriormente, obtém a certificação de Formação de Formadores e de Aptidão Pedagógica em 2006, com a classificação de Muito Bom e de Formação Profissional em Massagens (ocidental, drenante, Tui-Na e Shiatsu), 
Auriculoterapia, Automassagem e Reflexologia, em 2008, no Instituto Português de Naturologia, com a classificação global de Muito Bom.

A jovem estudante. Dificuldades sentidas no percurso académico e sentido de justiça

Pelo relato acima, além de outras peripécias descritas, infere-se que as dificuldades mais significativas ocorreram durante o desenvolvimento do CEC, que compreendia duas vertentes: ensino e administração. Em maio, muito cansada, acusando o desgaste físico e emocional, consultou o Dr. Nunes Vicente, seu professor, que a aconselhou a desistir, pois a labilidade emocional, a alteração de alguns parâmetros fisiológicos, como o metabolismo basal, indicavam que estava em esgotamento, cujas repercussões na sua vida futura seriam sérias. Não seguiu o seu conselho, mas praticamente pôs o estudo de lado. Valeulhe o investimento que tinha feito anteriormente, inclusive dando explicações de francês aos alunos da D. Odília e ela retribuía, esclarecendo-a nas suas dúvidas. Apresentou-se aos Exames de Estado, as notas baixaram, mas passou, obtendo os Diplomas da Secção de Letras do $2 .^{\circ}$ ciclo liceal e do CEC.

Para além destas situações específicas, houve outros acontecimentos marcantes que se encontram associados ao seu carácter de justiça e lealdade. $\mathrm{O}$ seu CEG foi o primeiro de três anos (Decreto-Lei 38884/52). Este Decreto-lei, no $§ 2 .^{\circ}$ do seu art. ${ }^{\circ} 1 .^{\circ}$, determina que os cursos funcionariam, tanto quanto possível, em regime de internato, aliás, confirmando o estabelecido no Decreto-Lei n. ${ }^{0} 36219 / 47$ e que a Portaria, n. ${ }^{0}$ 14482/53 torna obrigatório. Portanto, durante os três anos do CEG residiu no Lar que se regia por regras muito rígidas e as infrações eram punidas com rigorosos castigos, muitas vezes sem justificativa.

Atendendo às suas características, a Estudante Nídia foi, desde muito cedo, reconhecida pelas suas capacidades. Durante o Curso de Pré-Enfermagem, nas aulas de datilografia e contabilidade, aliada ao seu saber pessoal adquirido ao trabalhar com o pai, demonstrou ser muito capaz, sendo convidada para trabalhar na Secretaria dos HUC, substituindo funcionários em gozo de férias, dada a escassez de pessoal, funções que exerceu logo a seguir aos exames finais do Curso de Pré-Enfermagem e durante todo período de férias, não auferindo salário, mas apenas as refeições gratuitas. Durante este período travou conhecimento com muitas pessoas dos vários setores, facilitado por exercer o secretariado do Administrador e do Chefe da Secretaria, o que the promoveu o estatuto de intermediária em nome do grupo de estudantes e, por conseguinte, a obtenção de uma rede de cobertura importante no momento de realização de alguns eventos, como foi o caso da festa do ritual de Imposição do Véu. Este ritual estava no auge, tendo ocorrido nas comemorações de $S$. João de Deus (8 de março de 1953), com missa na capela dos HUC, traduzindo-se num verdadeiro rito iniciático. Perante a nobreza de tal acontecimento decidiram fazer uma grande festa, para a qual contribuíram os dotes culinários das estudantes que integravam o grupo. Para esta bela e farta festa não obtiveram qualquer ajuda das estudantes do segundo ano, finalistas, visto o curso delas ser de dois anos. Não aceitaram, pois, de bom agrado o facto de lhe terem retirado os bolos que tinham sobrado, até porque já tinham definido, em grupo, a quem os deviam oferecer. Perante tal comportamento, indagaram e conseguiram descobrir onde tinham sido guardados. Decidiram arrombar o armário e retirar o que lhes pertencia por direito. Já só restava um bolo, que foi partido em tantas fatias quantas eram as estudantes e todas assumiram a responsabilidade do seu ato. Os outros tinham sido consumidos nos «lanches» das alunas do $2 .^{\circ}$ ano.

Desta ação conjunta resultou um castigo coletivo que implicou o pagamento de 5 escudos a cada estudante para o arranjo da fechadura do dito armário. E por algumas delas terem assomado às janelas, quando as monitoras tinham saído, instadas para identificarem as colegas, não o fizeram, assumindo o delito como de todas. Foram punidas com o castigo coletivo de só poderem subir aos quartos acompanhadas de uma estudante do segundo ano. Este castigo foi sentido como muito injusto e agravou as relações com as colegas do segundo ano unanimemente apelidadas de «bufas e espias», pois thes imputavam a denúncia. Evidentemente que não eram todas, talvez até fosse uma diminuta minoria, mas como não se demarcavam a animosidade era contra o grupo. Os castigos coletivos sucediam-se.

Nas aulas de Sociologia abordou-se a temática dos Direitos do Homem, tendo tido um impacto muito importante nas estudantes, pois não era isso que vivenciavam no Lar. Revoltadas decidiram organizar uma comissão para falar destes castigos coletivos ao Professor Dr. Coriolano Ferreira, que, na qualidade de 
Secretário da Direção do Lar das Alunas Enfermeiras de Coimbra (LAEC), comunicou às responsáveis do Lar, Monitora-Chefe e Monitoras. Estas não apreciaram nada esta atitude das estudantes e exigiram um pedido de desculpas coletivo. A Nídia que fez parte dessa comissão, não considerou a hipótese de pedir desculpas por algo que achava justo e sofreu penalizações nas notas dos estágios do primeiro ano e na forma como passou a ser encarada, depois as coisas compuseram-se, tendo concluído o curso com a classificação de 16 valores.

\section{A mulher e a profissáo \\ A Enfermeira Nídia}

Inicia a sua atividade profissional como enfermeira estagiária no serviço de Psiquiatria dos HUC, em agosto de 1955 cumprindo o chamado «mês de estágio obrigatório» do curso, que tinham de desempenhar gratuitamente. Considera este mês como uma experiência maravilhosa e muito rica em aprendizagens, pois pôde implementar estratégias diferentes e ver os seus bons efeitos no estado de agitação dos doentes, o que foi muito gratificante.

No mês de setembro, de férias, recebe um telefonema da EEAF a convidarem-na para assistente, sendo responsável pela turma A e a colega Delmina Moreira pela turma B do Curso de Auxiliares de Enfermagem (CAE) e as duas corresponsáveis pelo governo do Lar do Castelo, onde ficaram alojadas com as alunas. Considera esta experiência também maravilhosa.

Com a abertura do Hospital de Santa Maria, uma das enfermeiras, com funções de chefia nos HUC, foi-se embora para ocupar no quadro a categoria de enfermeira chefe, o que despoletou uma reunião de urgência a 24/04/56 com as assistentes, no sentido de encontrarem uma solução para o problema, visto o serviço ser também Enfermaria-Escola. A Enfermeira Nídia aceitou, embora revelasse alguma tristeza por deixar a área de ensino, devendo apresentar-se no dia seguinte, precisamente o seu dia de aniversário, pelo que pediu para iniciar no dia 26 de abril, pedido que foi aceite. Passou então a chefiar os serviços de Dermatologia e Venereologia, que incluía internamento, consultas externas, laboratório e serviço de Raios X.

Segundo as suas palavras, «caiu de paraquedas», sem nenhum tipo de apresentação e orientação sobre o que deveria fazer e com uma equipa paupérrima. A única pessoa que a recebeu foi o Fiscal, Sr. Azevedo, a fim de fazerem o inventário, que passava à sua responsabilidade. Tinha na altura 22 anos, com poucos conhecimentos naquela área, confrontandose com prescrições médicas lacónicas do tipo «Raios $\mathrm{X}$ e mande vir para depilar», em relação às tinhas do coro cabeludo, mas quando?; «Para cola», em úlceras varicosas, o que é cola, bem era cola de zinco. Valeulhe a ajuda dos enfermeiros do Serviço de Homens. O único alerta foi sobre o lidar com as «meretrizes», em situação de prisão, as suas estratégias de fuga e os procedimentos burocráticos aquando da alta, de fuga ou de infringirem as regras instituídas. No serviço havia crianças e adultos com situações graves. Para as compreender, estudou muito, valendo-lhe o empréstimo de livros do médico que preparava o seu exame de internato.

Considera que teve a intuição para desenvolver estratégias eficazes com vista a lidar de forma profícua com as diferentes pessoas com que teve de se relacionar nesse contexto profissional, e no caso com estas pessoas que caíram na prostituição. A prova é que durante o período da sua chefia não houve qualquer fuga. Sempre foi respeitada. Com o médico Chefe do Serviço, logo no início, houve um desaguisado. Estava a fazer a consulta e pediu-lhe uma pinça. Pensou que se tratava de retirar uma crosta ou um pêlo. Ao levar-lhe a pinça, com maneiras nada corretas e, à frente do doente, criticou-a severamente, "uma pinça para fazer uma biopsia!". Respondeu-lhe calmamente "o que pediu, foi uma pinça". Passado um tempo, pede novamente uma pinça. Ela prepara o material de biopsia e deixa-o num aparador/mesa de rodas (étagère) que havia no corredor, perto da porta da consulta, levando-lhe uma pinça. Novamente um desaforo e críticas severas. Sem responder abre a porta e puxa o étagère, dizendo-lhe com firmeza, "quando quiser fazer uma biopsia peça material para uma biopsia e não uma pinça, senão terá mesmo uma pinça". Remédio santo!

Neste serviço viveu uma das mais marcantes situações, que determinou o rumo da sua vida. Diz respeito ao cuidado a uma doente que sofria de um cancro ulcerado na região da face e couro cabeludo, com destruição de algumas estruturas, como o olho e ouvido direitos, com cheiro fétido e, segundo a informaram fazia hemorragias em toalha, aquando dos pensos, em acentuado estado de debilidade e muito mal cuidada. A máxima da Senhora Enf. Belmira Lapa foi o seu guia «Não provocar dor nem fazer estragos». 
No segundo ano do CEG teve o privilégio de fazer o estágio de Cirurgia no Serviço chefiado por uma grande Senhora, que passou a ser para ela, uma pessoa e enfermeira de referência - a Sr. ${ }^{a}$ Enfermeira Belmira Lapa, que admirava pelas suas capacidades, pela doçura e «haneza de trato», pela sua humanidade. Ao ajudá-la num penso, esta Senhora que ia explicando o que executava e a necessidade de o fazer com gestos suaves, a certa altura disse-lhe que era preciso ter sempre em atenção dois aspetos: "Não provocar dor nem fazer estragos!". Foi um lema que assumiu desde logo, procurando trabalhar as suas mãos para que se transformassem numa ferramenta maravilhosa, numa ferramenta mágica, como escreve, no cuidado ao outro, procurando no seu exercício profissional fazer jus àquela máxima «Não provocar dor, nem fazer estragos!». Na sua convicção, as mãos são instrumentos privilegiados que permitem transmitir doçura, compaixão, amor e muitas outras mensagens, que sendo poderosas perduram por muito tempo ou mesmo para toda a vida. É pelas mãos que os enfermeiros materializam as suas conceções. O seu uso na realização dos diferentes procedimentos que caracterizam a profissão, técnicos ou puramente relacionais, torna a prestação dos enfermeiros única, e um instrumento de comunicação potente, transmitindo a sua interioridade e os seus valores. Julga, pelas apreciações que são feitas às suas mãos, que conseguiu fazer delas instrumentos privilegiados. Voltando à situação acima referida, ela foi de tal modo marcante que determinou o assumir definitivamente a Enfermagem como profissão, pois encontrou a sua essência subtil, como o perfume da rosa que não se vê, mas se sente. Tomou a seu cargo cuidar daquela senhora, usando as mãos, como ferramentas privilegiadas, na forma como tocavam aquele rosto mutilado, nos gestos muito suaves na limpeza das feridas, a fim de não haver hemorragias, e na elaboração do penso. $\mathrm{O}$ cuidado e o respeito pela dignidade daquela pessoa promoveram 0 estabelecimento de uma relação de empatia e confiança que transpôs o exigido profissionalmente, havendo acompanhamento posterior sem estar diretamente relacionado com as obrigações profissionais.

A partir desta experiência, não mais pensou em seguir outros rumos e quando a estimulavam a fazer um curso universitário ou a questionavam de não o ter feito respondia, convicta: "Busca quem ainda não encontrou e eu encontrei", referindo-se à essência que toca o âmago do seu ser e que conduz a um empenho sério, responsável e contínuo, no sentido da aquisição das competências necessárias para o seu exercício digno. No seu entender a enfermagem oferece oportunidades únicas de aprendizagem, de desenvolvimento e crescimento humano, de progressão espiritual e de valorização da própria vida. Após esta primeira experiência de chefia, foi Enf. Encarregada das Consultas Externas de Ginecologia e Urologia, de Cardiologia, esta incluía as Consultas do Pessoal e dos Estudantes Universitários e também do Serviço de Cardiologia Mulheres, EnfermariaEscola. Em 15 de maio de 1958, é empossada como Enfermeira de $2^{\text {a }}$ Classe. E, em julho desse ano, toma as funções de chefia do Serviço de Clínica Médica Mulheres (4. $\left.{ }^{\mathrm{a} M M}\right)$, Enfermaria Escola. Também, neste caso, inesperadamente. Com a abertura do Hospital de S. João do Porto, a Enfermeira que chefiava este serviço, aceitou o convite da Comissão Instaladora daquele hospital, para a categoria de Enfermeira Geral, meteu um mês de férias e já não voltou. Mais uma vez, se viu a conferir roupas e materiais com o Sr. Fiscal Azevedo, a tomar responsabilidades muito acima da sua categoria profissional.

Na sua opinião, a enfermagem não é necessariamente uma profissão que exija uma vocação prévia ou muito inicialmente determinada. Considera, isso sim, que é necessário dedicação, estudo contínuo e trabalhar com honestidade as suas potencialidades, as suas ferramentas, na intencionalidade de fazer bem ao outro. Isso permitir-lhe-á descobrir a essência da enfermagem e receber «oferendas» das pessoas aos seus cuidados que não têm preço e a vincularão definitivamente à profissão.

\section{A vida é uma construção de todas as experiências, na família, na sociedade e no trabalho.}

A Enfermeira Nídia soube conciliar a vida pessoal, familiar e profissional, tarefa difícil na época. Casa com Manuel Simões Salgueiro em 4/01/1959 e foi mãe de três filhos, com a assunção desse papel maternal cedo, pois sempre foi seu desejo ser mãe. Casou, mantendo o estado civil de solteira. Com o Estado Novo não era permitido continuar o exercício hospitalar, casada, só em 1962 esta legislação foi revogada. Claro que nesta opção foi apoiada pela Enf. Geral, Fernanda Gouveia Pinto. Tem a certeza que o 
Diretor do seu Serviço, também Diretor do Hospital sabia disso, mas não se dava por conhecedor. Se não estivesse ao corrente seria muito caricato ter a chefiar o seu Serviço uma jovem enfermeira grávida solteira, ele que era um católico convicto.

\section{A Enfermeira Professora e A Escola de Enfermagem}

A situação de casada e oficialmente solteira torna-se incomodativa. Transmitiu este seu sentir à Sr. ${ }^{a}$ Enfa . Gouveia Pinto, sua Enfa. Geral, que havendo uma vaga de Enfermeira Encarregada de Enfermaria-Escola sugere que a ocupe interinamente.

É empossada neste lugar da EEAF em três de novembro de 1959, na condição de interina e em comissão de serviço, funções que já exercia no Serviço de Clínica Médica ( $\left.4 .{ }^{\mathrm{a} M M}\right)$, que chefiava. Não sendo uma situação segura, candidata-se ao Concurso de Provas Públicas para a categoria de Auxiliar de Monitor do quadro de pessoal da EEAF, vindo a tomar posse em 1/04/1961, condição para poder concorrer à categoria de Enfermeira Encarregada de EnfermariaEscola. Candidata-se ao Concurso de Provas Públicas para esta categoria, tomando posse em 24/09/1962.

Mantêm-se neste serviço, apesar do Diretor ser substituído por outro, até à saída do Decreto-Lei n. ${ }^{0}$ 48166/67 de 27 de dezembro de 1967. Este DecretoLei promulga uma organização profissional tríplice da carreira de enfermagem, carreiras hospitalar, saúde pública e de ensino, revogando o Decreto-Lei 37418/1949. Não tinha, pois, outra alternativa senão ingressar na carreira de ensino, visto pertencer ao quadro de Pessoal da EEAF. Em 1 de janeiro de 1968, deixa oficialmente a chefia da Clínica Médica, que também deixa de ser enfermaria escola, para se integrar nas atividades docentes.

Fica para trás algo que lhe foi muito caro, de trabalho muito intenso, pois como diz «servia a dois senhores», ao hospital com as responsabilidades de qualquer outra enfermeira chefe e à EEAF, colaborando no planeamento de estágios e criando as condições para a sua realização, inclusive para a realização dos Exames de Estado, bem como tomando parte ativa na orientação, supervisão e avaliação dos estudantes de todos os níveis de ensino existentes à época.

Com recursos humanos «esqueléticos» e lotação sempre esgotada, paralelamente à gestão da unidade e à participação nas escalas das rondas, também a prestação de cuidados diretos, como diz «meter a mão na massa». Mesmo nas rondas a todo o setor feminino, pediatria, socorros urgentes e Reanimação/ Medicina Intensiva, com um só elemento para dois ou três serviços, não era possível ficar-se pela coordenação, e sempre havia situações graves, salas do bloco operatório a terem que ser postas a funcionar, entradas de urgência, pessoas em fim de vida a acompanhar... Também nunca se furtou a dar o seu contributo em estudos de investigação médica, comissões de escolha e de receção de materiais e equipamentos, condução de inquéritos disciplinares (dois) e outros.

Se foi um período muito trabalhoso, em que às 48 horas semanais exigidas tinha que adicionar outras suas, foi também muito gratificante e que lhe permitiu, ao deixá-lo para assumir a docência integralmente, levar na bagagem um leque alargado de experiências profissionais e conhecimentos muito diversificados, muito úteis, diz imprescindíveis, no desempenho das novas funções.

\section{Particularidades do seu percurso como Docente}

Como acima referido, inicia oficialmente funções de docência a 1/1/1968, mas efetivamente depois de entregar o serviço e o inventário (conferido peça a peça e, assinado por si e pelo Fiscal). Aliás, esta formalidade constituiu ponto de honra que cumpriu nas suas mudanças profissionais, talvez pelas suas próprias experiências de tomar a chefia de Serviços à deriva.

A mudança do seu exercício profissional não decorreu da sua vontade, mas da mudança de legislação. Importa salientar que o Decreto-Lei 48166/67 não prevê a categoria de Enfermeiro/a Encarregado/a de Enfermaria Escola, nem determina a sua transição para a nova carreira, simplesmente «A extinguir quando vagar». Com este novo diploma legal dá-se um grande salto em termos de vencimentos (no DecretoLei 37418/49 situa-se da letra S, com gratificações para as chefias, à X, no Decreto-Lei 48166/67 passa a situarse da letra I à U), no Ensino vai da letra I, para Diretor de Escola, a N para Auxiliar de Monitor. Uma vez que a categoria de Auxiliar de Monitor, à qual acedeu por concurso de provas públicas (e bem renhidas, dado o número de concorrentes para as vagas existentes) e, esta categoria era condição necessária ao concurso tanto de Enfermeiro Encarregado de Enfermaria Escola como de Monitor, com exigências semelhantes, 
seria lógico a transição para a categoria de Monitor, equiparado na nova carreira a Enfa Geral, letra L. Mas não, fica «pendurada» na letra S. No entanto, na EEAF são-lhe, de facto, atribuídas as funções de Monitora/ Enfermeira Professora, sendo responsável do CAE, com duas turmas e mais de uma centena de alunos, com a coordenação da parte teórica e estágios, ao mesmo tempo que leciona conteúdos das disciplinas de enfermagem, muito atrasados, devido à escassez de docentes e orienta vários estágios em simultâneo. Inicialmente experimenta um sentimento de grande injustiça, nessa época recebiam em espécie, os membros da equipa que coordenava auferiam um vencimento muito superior ao seu, acedendo à categoria de Auxiliar de Monitor (Letra N) sem a exigência de Concurso de Provas Públicas. Foi aconselhada a entregar o caso a um advogado, e reclamar superiormente.

Ponderou e resolveu ver o outro lado da moeda, preparar-se para o Concurso de Provas Públicas de Monitor, o que lhe permitiria atualizar conhecimentos na área do ensino/pedagogia e pressionar para que fosse aberto o concurso para monitor. São sempre processos morosos pelo que, só em 24/04/1970, toma posse da categoria de monitor, ainda na situação de interinidade, e do lugar efetivo em 21/01/1972. Em 15/12/1972 obtém o provimento no lugar de Enfermeira Professora.

Esta entrada na docência exigiu-lhe um esforço desmedido, num período crítico de saúde. Um parto muito arrastado, complicado por um grave problema respiratório decorrente das condições da última ronda hospitalar. Entra em insuficiência respiratória, com acentuada anemia, a resvalar para choque obstétrico. Dado o seu estado de debilidade foi-lhe interdito, pelos médicos que a assistiram, qualquer esforço profissional durante pelo menos quatro meses, a fim de que pudesse recuperar, uma vez que amamentava. Tinha passado só mês e meio. Recorda que por vezes a sua cabeça parecia oca e suportava muito mal os ruídos, pensa ser devido ao estado anémico que demorou a corrigir-se.

Foi um batismo nas atividades docentes duríssimo, mas com um saldo muito positivo, que os alunos desse curso não esquecem.Após terminar este CAE, em março de 1969, passa de imediato a coordenar o Período de Enfermagem Médica e Doenças Infetocontagiosas (DIC), para logo de seguida coordenar o primeiro ano do CEG 1969-1972,
Enfermagem Preliminar e Enfermagem Médica e DIC. Manteve-se no primeiro ano até ser necessário coordenar o Curso de Promoção de Auxiliares de Enfermagem a Enfermeiros, Curso Intensivo de 20 meses (Ano letivo 1972/73).

Seria fastidioso enumerar em detalhe as atividades docentes realizadas. Resumindo, além dos Cursos citados, passou por todos os períodos e áreas do Curso de Enfermagem Geral, coordenando-os e lecionando algumas das suas disciplinas, coordenou o Curso de Especialização em Enfermagem Médico-Cirúrgica e o de Administração de Serviços de Enfermagem. Lecionou um leque diversificado de disciplinas: Enfermagem (Preliminar, Médica e DIC, Saúde Pública, Psiquiátrica), Ensino e Dinâmicas de Grupo, Patologia Geral, Medicina, Alimentação e Dietética, Investigação e Investigação Aplicada à Administração, Enfermagem (abordagem histórica da formação e como profissão, bem como aspetos emergentes e atuais), Enfermagem Médico-Cirúrgica, Tendências de Enfermagem nos Cursos de Administração dos Serviços de Enfermagem e de Pedagogia Aplicada ao Ensino de Enfermagem, Ética e Deontologia Profissional nos cursos de que foi responsável e em aspetos específicos noutros cursos. Mesmo depois de se aposentar, este é um assunto que lhe é muito caro. Poder-se-á questionar o porquê de diversos cursos e diversas disciplinas. A verdade é que obedeceram a imperativos que não os seus. Como diz, «quando me começava a sentir "como peixe na água", tinha que começar nova caminhada». É o caso do Curso de Especialização em Enfermagem Médico-Cirúrgica (CEEMC). «Começámos do zero, socorrendonos de tudo o que pudemos, inclusive de amigos estrangeiros, fomos pioneiros nos seus conteúdos opcionais, respetivos seminários e trabalhos de investigação, desbravámos terreno para os estágios, como o caso do Bloco Operatório e da Higiene e Prevenção das Infeções Hospitalares, visitámos Hospitais e instituições de outros países para que os estudantes observassem in loco determinados projetos a funcionar, muito antes de entrarem no nosso País, caso da avaliação e controlo da dor, de unidades de estomaterapia, da litotrícia, de sistemas de informaçãa eletrónicos, etc., etc.». Quando se sentia confortável, eis que lhe é pedido para iniciar o Curso de Administração de Serviços de Enfermagem (CASE) e lecionar a disciplina de Investigação Aplicada à Administração e a de Tendências de Enfermagem. 
"Ainda resisti algum tempo, até porque era necessário fechar o CEEMC, mas os argumentos venceram-me. O CEEMC ficava bem entregue, não tinha dúvida, tínhamos formado equipa, mas o CASE? Poderia dar o que de mim era esperado?".

Os testemunhos das pessoas que conhecem a Enf. ${ }^{a}$ Nídia e o seu percurso são unânimes em dizerem que após algumas reticências tomava os novos projetos como desafios, envolvia-se neles a fundo e davalhes um cariz particular, muito próprio, como, por exemplo, o caso da investigação.

A par das atividades docentes na EEAF, foi Delegada da Direção Geral dos Hospitais nos Exames de Estado das Escolas de Enfermagem privadas, Rainha Santa Isabel (1970/1971), em Coimbra e Lopes Dias, de Castelo Branco (1973/1974), esta, depois, tornada pública. Integrou sempre os júris dos Exames de Estado (Provas escritas, orais e práticas) da EEAF. Fez parte de Júris de vários concursos da carreira docente e de Enfermeiro Supervisor nos HUC. Integrou o Grupo de Revisão do Curso de Enfermagem, Plano de Estudo e Programas, cujas atividades se iniciaram em janeiro de 1974. Quando se deu o 25 de abril e o grupo foi desfeito, já estavam apurados os resultados de questionários lançados a nível nacional e definidas linhas orientadoras. Todo o material foi entregue ao novo grupo, nomeado em setembro de 1974 e, certamente tido em conta na elaboração do chamado «Livro Verde» (1977).

Em 1974 estava no auge das suas capacidades, no entanto, o final do $1 .^{\circ}$ trimestre foi um pouco conturbado pela dificuldade em conciliar a orientação dos estágios do segundo CPAEE, nos moldes e nível de exigência habituais, as idas a Lisboa para as atividades do grupo de revisão do Curso de Enfermagem, um dia por semana, e os exames finais (estágio) do CAE da Escola de Enfermagem Lopes Dias, que ocorreram em Castelo Branco e nos Hospitais Civis de Lisboa. Embora já sendo Escola Oficial, foi entendido superiormente que o Júri dos exames anteriores (julho 1973) se devia manter e, ainda lecionar algumas disciplinas que, por imperativo da Escola, tiveram que assumir. Houve algumas divergências com a Diretora que foram sanadas com diálogo franco. No dia 25 , às 8 horas estava a lecionar as suas aulas, cheia de entusiasmo, em dinâmicas de grupo, só se apercebendo, ela e os estudantes, que tinha havido qualquer coisa ao fim das duas horas de trabalho.

Quarenta anos, plena de vitalidade, a fazer o que gostava, desdobrando-se em atividades diversas, estágios, aulas, aulas de natação à comunidade escolar, pois instada pela Direção Geral dos Desportos (DGD) a candidatar-se às provas para obtenção do certificado de técnico de natação, foi aprovada (fig. 4). A DGD, com este convite e argumentação dada às suas reticências, premiava o seu trabalho nas Escolas de Natação e o acompanhamento desta atividade desde 1969, ano em que foi responsável pela sua introdução na EEAF (Salgueiro, 2010). Exames exigentes, cujas provas ocorreram de 18 a 23 de dezembro de 1971, sob a responsabilidade de técnicos superiores do Colégio de Treinadores Espanhol, em que só obtiveram certificado 33 dos 68 candidatos de todo o País, que já ensinavam natação. Ficou posicionada em 12. ${ }^{\circ}$ lugar, ex aequo com outro. Nos primeiros lugares ficou a "fina-flor" dos professores de Natação de Coimbra, e seus professores, antigos nadadores, detentores de recordes nacionais e até em competições internacionais, licenciados em várias áreas. A par destas atividades a ginástica no CPAEE e as atividades culturais. Também foi introduzido o judo para os rapazes.

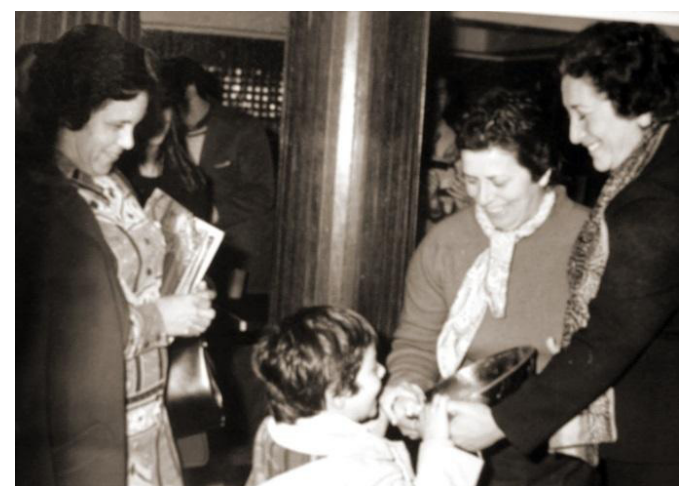

FIGURA 4 - Festival de Natação, incluído na festa de encerramento do CEG 1969-1972 realizado nas piscinas municipais de Coimbra, setembro 1972, em que o seu esforço foi premiado com uma grande taça de cobre.Da esq. para a dir. Dulce Augusta M. Pinto, Nídia Salgueiro, Maria dos Anjos Narciso e ao centro Rui Pedro Salgueiro.

Os movimentos antifascistas saneavam diretores, professores, detentores ou não de cargos políticos, sem critério aparente. Dizia-se, perante esta onda de saneamentos dos chamados fascistas que «fascista é todo aquele que tem um lugar que eu quero». Alguns dos Saneados foram reabilitados e até homenageados, como o caso do Diretor da Faculdade de Medicina e de alguns Professores da Universidade. 
$\mathrm{Na}$ Escola, os primeiros tempos foram relativamente pacíficos. Ao abrigo da Portaria 34/70 (Regulamento Geral das Escolas de Enfermagem), decorrente do Decreto-Lei n. ${ }^{\circ}$ 48166/67, que cria a carreira de ensino, a Monitora-Chefe, Senhora D. Dulce Augusta Magalhães Pinto, é empossada no lugar de Diretora da EEAF, em 1972. Terá sido a primeira, senão uma das primeiras enfermeiras a deter esta categoria. Não é fácil gerir uma Escola de Enfermagem e, por inerência do cargo também presidente da Direção do LAEC, que no momento tem em funcionamento seis casas entre lares de estudantes e residências de Enfermeiras e Auxiliares de Enfermagem, onde também habita, com os poderes que lhe confere esta Portaria, por exemplo, no ponto 8 do art. $13 .{ }^{\circ} \ldots$ exerce na escola toda a autoridade sobre pessoal e alunos, e pode tomar, em caso de urgência, medidas que sejam da competência própria de algum dos órgãos de administração ou direção, submetendo-as depois à ratificação. Há já um princípio democrático com vários órgãos onde os alunos estão representados, que lhe compete presidir. Não é fácil a quem está nestes cargos, agradar a todos e fazer cumprir as restrições impostas pelos pais das jovens. Nestas circunstâncias não é de admirar que houvesse algum descontentamento, sobretudo em relação aos lares.

A Direção manteve-se mas foi criada uma comissão alargada, em paralelo, a Portaria previa essa possibilidade, que incluía a Diretora. Houve da sua parte alguma dificuldade em gerir a situação, com reuniões em horários sobreponíveis que geraram malestar e as tensões foram-se avolumando.

Entretanto os movimentos sindicais conseguem a aprovação de vários textos legislativos: fim dos exames de estado, passagem dos Auxiliares de Enfermagem a Enfermeiros de 3. a classe, passando a haver um só nível de ensino de base, suspensão do CPAEE de 20 meses, sendo substituído por um outro de passagem dos Enfermeiros de 3. ${ }^{\text {a }}$ Classe a Enfermeiros, de menor duração e fora do âmbito da Escola. Não é fácil gerir todas estas modificações.

Em setembro, a Diretora integra o novo grupo de revisão do Curso de Enfermagem.

Quanto à Professora Nídia, sofre de um grave acidente de viação, o seu alerta de que tinha uma perfuração intestinal não foi aceite pelo médico que a assistiu na urgência. Esteve 48 horas com uma perfuração alta, cujo diagnóstico só foi feito quando recorreu ao médico com quem tinha trabalhado, Dr. Freitas
Tavares, seu amigo. Foi operada em situação extrema, 15 dias depois o seu estado agrava-se e mais uma vez é o médico, seu amigo, que the diagnostica um enorme abcesso retroperitoneal. Esteve um mês internada e o que the valeu foi a boa forma em que se encontrava aquando do acidente. Ainda internada começou a ser visitada no sentido de que integrasse o movimento revolucionário contra a Diretora, lembrando-lhe as divergências que tinha tido com ela. De facto tinha havido atitudes de que não tinha gostado, mas isso estava resolvido entre as duas. Quando regressa ao trabalho, muito debilitada, a situação era muito tensa. Estava marcado um Plenário, a Diretora pedelhe para presidir a esse plenário, substituindo-a, uma vez que tinha reunião em Lisboa no grupo de trabalho. Comprou um livro sobre a regência das assembleias, para estar à altura da incumbência, «Santa Ingenuidade!». Com os ânimos exaltados, o Plenário arrasta-se, os presentes vão saindo. Do estrado, onde estava a mesa e frente à assembleia, podia ver as manobras em que os estudantes do $1 .^{\circ}$ ano eram simples marionetas, comandados por um grupo ao fundo da sala. Debilitada e triste com o que presenciava só pedia ao Alto que da Assembleia viesse um voto de desconfiança que acabasse com tal situação. O Plenário acabou de madrugada, restando um grupo relativamente pequeno a constituir uma Comissão para tomar conta da Escola e sanear a Diretora. Ela já não voltou a Coimbra.

Muitos outros plenários aconteceram. Sempre esteve presente e foi interveniente. Os docentes que participavam, ou entravam mudos, mostravam-se e saíam calados, ou mais politizados intervinham num discurso dúbio, mas aliciante das massas. Recorda um plenário que se arrastou até de madrugada, dirigido pela comissão que assumiu a direção da Escola, dois docentes, uma administrativa, uma Auxiliar e estudantes. O assunto principal era retirar o vencimento à Diretora. As discussões arrastaramse, as pessoas debandaram e quando chegou à discussão de assunto tão sério, estavam presentes 21 pessoas. As suas intervenções foram no sentido de que o Ministério tinha serviços aos quais cabia fazer inquéritos disciplinares e apurar se havia ou não matéria para aquela sanção. Não adiantou e a proposta foi aprovada por «maioria esmagadora», de braço no ar. Como o assunto era sério, foi-lhe enviada a ata para assinar, ao que respondeu que só o faria depois de constar qual era a esmagadora maioria 
referida no documento, 18 a favor e três contra, a Prof. Nídia, a funcionária administrativa e a auxiliar que pertenciam à dita comissão. Até hoje está à espera de assinar a tal ata, mas esta foi enviada superiormente, e o vencimento da Diretora suspenso. Feito o inquérito, recebeu junto o montante do ordenado de três anos, mas só não passou fome porque a família a ajudou.

Tinha relações privilegiadas com os estudantes, fruto dos momentos de descontração vividos nas aulas de natação, ginástica e atividades circum-escolares de índole cultural. Naqueles tempos conturbados quase não podia falar com os estudantes, os contactos, mesmo a natação eram vistos como manipulação. Deixou estas atividades, que rapidamente terminaram, por não terem quem as dinamizasse e aproveitou para fazer um estágio na Unidade de Cuidados Intensivos Coronários (UCIC) do Hospital Geral do Centro Hospitalar de Coimbra (CHC), devidamente autorizado.

A indisciplina que se vivia levou-a a tomar posições drásticas, devidamente comunicadas aos órgãos da escola e que constam do seu processo.

Confessa, que neste período conturbado esteve tentada a aceitar o convite do Serviço de Medicina Pedagógica para integrar o seu quadro de pessoal. Depois de profunda reflexão, no derradeiro momento, achou que o não devia fazer. A Escola que muito amava precisava do seu contributo. Estava desacreditada e necessitava de obter outro nível de visibilidade. Decidiu dar essa oportunidade a uma colega que sabia estar interessada, cedendolhe o lugar, que aceitou. Julga ter tomado a opção certa. $\mathrm{O}$ ambiente de trabalho mais tranquilo não compensaria, por certo, o sentimento de traição que sentiria se abandonasse a sua Escola, num momento crítico, em que tanto precisava da ajuda de todos.

Em 1976, retoma as relações com a Direção Geral dos Desportos. Há muito que desejava realizar um projeto sobre A Prevenção de Doenças Cardiovasculares pelo Movimento, em pessoas de risco: obesos, diabéticos, com processos anginosos e em risco de enfarte do miocárdio. Quando fez o estágio na UCIC, tinha falado nisso ao seu Diretor Dr. Ubach Ferrão, pois tal projeto não era realizável sem a cobertura médica de um serviço de cardiologia. Mostrou-se recetivo, mas era necessário que a EEAF pudesse disponibilizar um grupo para acompanhar os participantes. O GPS do Universo encarregou-se do assunto. Na perspetiva de novo plano de estudos (Livro Verde) e com a saída de docentes da área de Saúde Pública, não havia quem aceitasse a coordenação desta área e a de Ensino e Administração. A reunião de distribuição de atividades foi renhida. Perante este beco de que se não vislumbrava saída, a Professora Nídia ofereceuse - confessa que o fez no fogo da discussão sem muito pensar nas consequências, simplesmente para resolver o impasse, impondo, como condição, ser-lhe permitido pedir a colaboração de enfermeiras com formação e experiência em Saúde Pública (Centros de Saúde), que foi aceite. Quando caiu em si, deu-se conta que as novas funções lhe permitiriam realizar o projeto através do estágio dos estudantes sob sua orientação e, no início de 1977, o projeto, numa organização tríplice: EEAF, Serviço de Cardiologia do Hospital Geral e DGD, avança com 50 participantes aprovados do ponto de vista médico, que os nossos estudantes acompanham desde os exames médicos, e respetivos exames bioquímicos e outros complementares de diagnóstico, no Hospital Geral do CHC até às atividades no Circuito de Manutenção do Choupal, fazendo a supervisão sob o ponto de vista de saúde (pulso, TA, respiração e sinais de cansaço, etc.) orientação e ensino de acordo com os seus problemas. E colaboram em todas as atividades inerentes ao Lançamento do Desporto para Todos. Em maio de 1977, foi apresentado o projeto nas Jornadas Internacionais de Cardiologia Preventiva, organizadas pelo Prof. Doutor Fernando Pádua e, em 1978, foi realizado um Ciclo de Conferências «Desporto para Todos, Saúde e Movimento», numa organização conjunta DGD e EEAF.

Quando instituía este projeto e o do Desporto para Todos, os estágios dos estudantes no Centro de Saúde da Mealhada, Medicina Pedagógica e no acompanhamento dos participantes no Projeto Prevenção Cardiovascular pelo Movimento, cheia de entusiasmo, surgem as eleições para a Comissão Instaladora. Apesar de expressar que não estava interessada e de solicitar aos colegas que não votassem nela, surge como a mais votada no setor. Havia ainda uma esperança, visto que a decisão seria dada pela votação em Assembleia Geral, por todos os setores da Escola. Reforça o pedido aos colegas docentes e aos membros do Setor dos Serviços Administrativos e Auxiliares de não votarem em si. Esta Assembleia Geral ocorre no Instituto Justiça e Paz. Enquanto se preparam as eleições, vem para a varanda orar para não ser eleita. Coisa estranha, começa a receber 
informação contrária ao seu pedido, argumenta mas surgem contra argumentos fortes. Entra na sala plenamente convicta que não se livrava de integrar a Comissão de Instaladora e, assim aconteceu. Não consegue recusar, para espanto dos seus amigos que de facto não tinham votado no seu nome. «Ao menos podia ser eleita com mais votos». Pois é, «uma coisa é o que se quer, outra é o que o Universo manda!». Depois houve que explicar o que aconteceu quando veio para a varanda. Toma posse em 24/02/1977 e da Comissão de Gestão em 19/02/1981, de que foi exonerada a seu pedido em 4/05/1983, dado o cansaço dos dois últimos anos. Em 10/05/1985, foi investida no Conselho Pedagógico Científico.

A Portaria n. ${ }^{\circ}$ 674/76 considera 3 ou 5 pessoas na constituição da Comissão Instaladora/Gestão, representando os três setores. No caso da EEAF: 2 docentes, 2 discentes e 1 do setor Administrativo e Auxiliar, não são previstos o voto de qualidade, nem a figura de presidente. Trabalhar em situação de igualdade com estudantes das várias opções políticas foi uma experiência deveras interessante que exigiu respeito mútuo, sinceridade, honestidade e resultou no estabelecimento de laços de amizade que ainda hoje perduram, e de que se orgulha, diz. Mas não foi fácil. Tinha havido «a ditadura dos estudantes», que deixou feridas difíceis de cicatrizar, sobretudo nos docentes. Depois foi o reverso da medalha. Por vezes parecia que se estava debaixo de fogo cruzado. As relações estabelecidas com a Associação de Estudantes foram as melhores possíveis e as conversas com o seu Presidente, geralmente ao fim da tarde, ajudaram a resolver problemas.

Depois de profunda reflexão, ao integrar a Comissão Instaladora sabia o que queria para a Escola, tinha bússolas orientadoras, claro que como diz, não dependia só de si. Ao deixar estas funções, o balanço foi muito positivo em termos de atingir os grandes objetivos que nortearam o seu trabalho.

Eliminar tensões entre docentes e estudantes e melhorar o nível de ensino eram das suas primeiras prioridades tendo sido conseguidas.

A Escola abriu-se à comunidade e ao exterior. $\mathrm{Na}$ sua ideia as novas instalações deveriam ser usadas e rentabilizadas de forma responsável, tal como a Escola teve a ajuda de outras instituições quando as suas instalações eram muito precárias. Era agora a sua vez de socorrer outras, cedendo o auditório, salas de aula e alojamentos na residência escolar a outras instituições e organizações, sem prejuízo das atividades. Estabeleceram-se assim relações de cooperação com a Universidade, Câmara Municipal, Governo Civil, Alliance Française, Casa de Inglaterra, Instituições Culturais, Desportivas e outras e, bem entendido, na área da Saúde. Quem dá recebe e a Escola recebeu muito, nunca the sendo negado qualquer pedido de colaboração. Foi também estabelecido acordo de cooperação com a Escola de Educadoras de Infância para alojamento das suas estudantes na Residência da Escola. Este acordo foi sancionado a nível dos dois Ministérios envolvidos.

Através deimensos programas de formação, organizados pela própria Escola ou em colaboração com outras entidades, procurou satisfazer as necessidades de formação dos enfermeiros da sua região e da própria comunidade. Tendo em conta as alterações surgidas no contexto da enfermagem, especificamente na progressão na carreira e, de acordo com o estipulado no Decreto-Lei $n^{0}$ 305/81 de 18 de novembro, era premente que Coimbra pudesse oferecer aos Enfermeiros da Região Centro formação pós-básica. Num esforço conjunto da Comissão de Gestão da Escola, do Corpo Docente e Pessoal Administrativo, o assunto foi estudado e foi proposta superiormente a abertura de Cursos de Enfermagem Pós-Básicos. A 20 de junho de 1982, o Secretário de Estado da Saúde autorizou que «na Escola de Enfermagem Dr. Ângelo da Fonseca funcionassem os Cursos Pós-Básicos existentes e os que viessem a ser criados». Um mês depois entrava em funcionamento o primeiro curso. Em todo este processo teve a ajuda de instituições de saúde e outras. A EEAF passa a ser considerada Pós-Básica pelo Decreto-Lei n. ${ }^{\circ}$ 265/83 de 16 de junho.

O trabalho nas Comissões Instaladora e de Gestão não foi fácil. Havia «vícios» a corrigir, como o caso do Lar Alexandre Herculano (Salgueiro e Carvalho, 2007); contratos a rever, como o fornecimento da alimentação do Lar Sede, em total descontrolo; a mudança para as novas instalações, não testadas no seu funcionamento, verificando-se graves deficiências, pessoal auxiliar e orçamento muito deficitários, dado que vinham dos HUC, tendo a seu cargo os serviços de apoio e manutenção, em que alguns eram comuns. Mas as necessidades levaram também a decisões arrojadas para a época, como a transformação do Lar Sede, de Lar feminino a misto, balão de ensaio para que a Residência da Escola começasse a funcionar para os dois géneros, com sucesso. 
A criação de um Fundo Social em virtude de não haver qualquer verba para despesas de representação, para oferecer um café a quem os visitava ou para a Escola se fazer representar no funeral de alguém que lhe estava ligado ou numa qualquer cerimónia. A primeira festa de Natal nas novas instalações foi uma tristeza. Com o contributo de todos houve «lanche» e atividades para as crianças, mas não foi possível dar-lhes uma prendinha, por modesta que fosse. Nesse dia, a Professora Nídia, triste, pensou que não era justo, pois todos os funcionários trabalhavam tanto para rentabilizar as instalações! Prometeu a si mesma resolver a situação. Com a ajuda da Senhora D. Naldi, Chefe dos Serviços Administrativos, perita em assuntos de legislação estudou a situação, chegando-se à conclusão que a aplicação de uma taxa de $5 \%$ sobre os serviços prestados seria suficiente. Elaborou-se o respetivo regulamento, estabeleceu-se contabilidade própria, deu-se conhecimento superior, por ofício e na ausência de resposta em contrário entrou em funcionamento. A quem procurava os serviços era explicada a situação, havendo lugar a duas faturas, a da Escola e a do Fundo Social. A Associação de Pais pediu o auditório e salas para três dias e o fornecimento de refeições. A senha de refeição era vendida habitualmente ao preço de $100 \$ 00$, passando a 105\$00. Qual não é o seu espanto quando se apercebe de que teriam sido pagas a $120 \$ 00$, tendo sido entregues os $20 \$ 00$ para o fundo social, pois achavam que os $5 \%$ eram insuficientes para pagar as atenções e os serviços recebidos. Foi um bom começo.

Ao deixar a gestão da EEAF, houve decisões que são contestáveis e foram-no. Por vezes foi mesmo necessário «pegar na bússola, traçar o caminho e ir em frente, arcando com as responsabilidades das decisões». Mas, orgulha-se de que nas Celebrações do Centenário da Escola, a EEAF recebeu duas Medalhas de Ouro, do Ministério de que dependia e da Câmara Municipal de Coimbra. Também, devido ao trabalho com DGD, foi considerada Instituição de Mérito Desportivo. O ano do Centenário, com comemorações de várias efemérides foi muito trabalhoso, mas muito gratificante.

\section{Contributos na área da formaçáo}

É inegável o seu contributo em atividades formativas, quer como Presidente das Comissões Científicas de congressos, jornadas, simpósios e outros, quer como palestrante. Como júri de avaliação e seleção de candidaturas de pósteres ou comunicações orais, é bem conhecida a sua forma de estar, a sua postura educativa em contactos escritos ou entrevistas para as necessárias correções ou orientações para futuros trabalhos.

Também nos tem legado trabalho escrito, publicado tanto em modestas revistas como na nossa conceituada Revista de Enfermagem Referência, a Revista do CICIAMS. Considera seu dever deixar o seu contributo para que um dia se faça a história da enfermagem. Chama-lhe apontamentos para a história, mas de facto são apontamentos que têm por trás muita pesquisa e estudo.

A tradução de livros de investigação, na área da Comunicação em Enfermagem e do Envelhecimento perturbado e outras, assim como uma enorme quantidade de documentos, é uma preciosa contribuição.

A Sr. ${ }^{a}$ Professora Nídia integrou a Comissão Científica do BISE (Boletim Informativo dos Serviços de Enfermagem dos HUC), pois sempre considerou que a criação de um órgão de informação se revela de extrema necessidade para o desenvolvimento profissional, na medida em que permite a partilha de saberes, experiências, formas de estar e de fazer entre os seus diferentes membros constituintes. Era importante motivar os profissionais para a produção de conhecimento e sua divulgação, assumindo o papel de produtores e consumidores de informação, pois como refere "Quem mais tem mais tem que dar!". No papel de coordenadora do Curso de Especialização em Enfermagem de Médico-Cirúrgica, criou com os alunos a Associação de Enfermeiros Especialistas em Enfermagem Médico-Cirúrgica, de que foi Presidente da Direção durante mais de 10 anos. No âmbito desta Associação, foram realizados dois Congressos Internacionais de Enfermagem Médico-Cirúrgica, com grande sucesso em trabalhos apresentados e várias jornadas, umas de âmbito temático e outras de âmbito genérico, um curso de investigação, sempre com a participação de personalidades estrangeiras de reputada competência. Criou-se um órgão de informação «Cuidar». Promoveram-se visitas de estudo, de âmbito cultural e profissional, no país e no estrangeiro, bem como o acolhimento de grupos estrangeiros em visitas de estudo.

No âmbito do Desporto para Todos, foi criada a Associação do Desporto para Todos, com a secção 
Caminheiros, tendo feito parte dos seus corpos sociais e colaborado na organização de ações de sensibilização para a criação de grupos congéneres e Encontros Nacionais e Internacionais de Caminheiros. Desde2005, queestáenvolvida no MétododeCuidados em Humanitude e a partir da coorientação duma tese de doutoramento, com aplicação no terreno, mais profundamente. Neste momento, está concluída e aceite, à espera de marcação da sua discussão. Fez formação com os autores do Método, Yves Gineste e Rosette Marescotti e ajudar a criar o IGM (Instituto Gineste - Marescotti) Portugal, em março de 2011, sendo Diretora Técnica. Este método, que prima pela suavidade dos gestos cuidativos, pelo toque-ternura, veio ao encontro daquilo em que acredita. De facto, verificam-se milagres com diminuição da agitação e oposição aos cuidados em doentes atingidos de demência; baixa acentuadamente o consumo de neurolépticos e a acamação, tendo-se verificado baixa na taxa de absentismo. Gostaria de deixar esta oferenda aos seus pares.

O seu gosto pela multiculturalidade e a facilidade com que se relaciona com as pessoas facilitou-lhe o contacto com entidades importantes no mundo da enfermagem internacional, cujas relações estabelecidas se revelaram produtivas na medida em que the possibilitaram o conhecimento de projetos inovadores e muito úteis e a tradução e integração de obras importantes.

Desta forma, a Escola de Coimbra adquiriu muita visibilidade e estabeleceu relações profícuas a nível internacional que ainda hoje perduram.

\section{Como se vê e como os outros a vêem...}

Considera-se uma faladora nata, uma pessoa extremamente poupada e com capacidade de aproveitar tudo o que a natureza oferece, reciclando e reutilizando. Na sua ideia não foi afortunada com o sentido de organização, no entanto, esta perceção contraria todas as apreciações que lhe são incutidas pelos outros. Refere que os seus Amigos da Natação e do Desporto para Todos um dia lhe disseram que o que mais admiravam nela era a capacidade de organização. Riu-se, "essa não, admito que a organização não é o meu forte" Em resposta "está a confundir as coisas, a Nídia tem uma organização dinâmica, num relançamento contínuo". Vendo-a não convencida, chamam-lhe a atenção para os diversos projetos que leva até ao fim com pleno êxito.
O alto nível de conhecimentos demonstrado, quer no que concerne à profissão de enfermagem como à cultura portuguesa, é reconhecido por todos aqueles que têm o privilégio de privar com a sua pessoa.

Da análise ao livro de honra existente na biblioteca da Escola Superior de Enfermagem de Coimbra - Polo A, e da Associação de Enfermeiros Especialistas em Enfermagem Médico-Cirúrgica, pode constatar-se que inúmeras pessoas, de diferentes nacionalidades fazem uma apreciação unânime às suas qualidades pessoais e como anfitriã de inúmeros eventos científicos. Esta apreciação passa pela caracterização como uma pessoa extraordinária, dinâmica, gentil, que revela disponibilidade constante para com os outros, demonstrando a «arte» de bem receber inerente à população portuguesa. A sua capacidade de acolhimento aliada à sua vertente humanista e calorosa possibilita-lhe uma organização cuidada e culturalmente rica a todos os visitantes da cidade de Coimbra e da escola, proporcionando momentos únicos e inesquecíveis, sendo por alguns intitulada como «Embaixadora de Portugal» espelhando um marco na cultura portuguesa.

Se isto é verdade em termos culturais, em termos de divulgação e partilha de conhecimentos científicos da área de enfermagem, a sua dedicação não revela qualquer grau de descuro. A organização de determinados eventos científicos, de carácter nacional e internacional, proporciona a troca de experiências, a partilha de saberes, o sucesso educativo alcançado, aliando uma visita de rara beleza à aquisição e aprofundamento de um conjunto de saberes de enfermagem, que enriquecem os seus profissionais na vertente do ensino ou da prática clínica. Estas experiências enriquecedoras contribuem para a sua caracterização como mulher carismática, entusiástica, dinâmica e sabedora, revelando com gentileza a sua paixão pela enfermagem. O seu contacto com escolas de diferentes países proporcionou a troca de informações e conhecimentos úteis para o desenvolvimento da profissão, que ela utilizava para motivar os seus pares no sentido da valorização da enfermagem.

Humilde na sua apreciação pessoal, considera que se dedicou e continua a dedicar à enfermagem com paixão, mas que poderia ter feito mais, nomeadamente em termos de escrita dos seus contributos para o desenvolvimento da profissão. No entanto comunga a ideia de que o «GPS do Universo» é sábio e que terá 
realizado o que o mesmo considerou necessário e essencial. Na sua perspetiva, a enfermagem é subtil e serão as pequenas coisas que a caracterizam, que a enaltecem e transformam numa profissão única, inigualável e maravilhosa.

O seu corpo fala constantemente, pelo seu olhar, pelo deslizar suave das suas mãos, pelo calor apaziguante que emana e pela tranquilidade e serenidade que oferece aos que com ela partilham momentos, transmitindo a sensação de superação e resolução de alguns problemas e angústias. Imaginem o efeito benéfico e salutar desta postura junto de um ser que sofre e reflitam sobre o seu resultado e contributo, complementarmente a qualquer técnica, eximiamente desenvolvida.

Por tudo o que foi referido, teve de render-se às evidências e passar a considerar-se uma pessoa reveladora de sentido de organização, embora o seja de forma diferente e única, na medida em que apresenta uma capacidade de trabalho e de relacionamento de assuntos invejável, fruto da sua perspicácia e atributos intelectuais, demonstrando uma ligeireza e pertinência de raciocínio surpreendente e invejável.

Considera-se uma pessoa afortunada, pois sempre recebeu manifestações de apreço tanto dos Diretores dos Serviços que chefiou, em declarações escritas, como da Ordem dos Enfermeiros a tornou Sócia Honorária, como da Direção dos Serviços de Enfermagem dos HUC que lhe atribuiu o Prémio Dedicação e Empenhamento 2001 e o Prémio Prestígio 2004; como do Ministério da Saúde que distinguiu o seu empenhamento nas Jornadas de Enfermagem Primavera atribuindo-lhe, em 2007, a medalha de Serviços Distintos (Medalha de prata).Por sua vez, a Escola Superior de Enfermagem de Coimbra deu o seu nome a um dos seus laboratórios. Aquecelhe a alma as manifestações de amizade das pessoas que vai encontrando no caminho, o carinho dos seus ex-alunos, a consideração de médicos e membros de outros estratos profissionais

\section{Complementaridades}

Para além do seu fascínio pela enfermagem, nas suas diversas dimensões, a sua vontade de ajudar e a capacidade de dar de si com a intenção de promover bem-estar e saúde aos outros sempre a acompanhou. A sua postura educada e respeitosa sempre lhe permitiu encarar os seus congéneres como seus semelhantes e equivalentes enquanto cidadãos, o

que lhe exigiu a interiorização de que a sua prestação técnica e específica deveria estar impreterivelmente associada a um investimento sentimental e afetivo significativo.

Desenvolve competências a vários níveis, fazendo formação na área do Reiki, Massagens Ocidental, Drenante, Desportiva e Automassagem e Reflexologia. As suas mãos, ferramenta mágica como lhe chama, permitem tocar, aconchegar, embalar, cuidar de nós próprios e dos outros, ganhar o nosso sustento, manifestar a nossa criatividade e até agradecer pelo trabalho que realizamos quando as erguemos ao Pai. Partilhando a sua crença religiosa, compreende-se a analogia realizada em torno da Rainha Santa Isabel, padroeira da cidade onde se formou como enfermeira e onde aplicou todo seu saber ser, estar e fazer em prol dos que necessitavam. Segundo a Sr. ${ }^{a}$ Professora Nídia, a ilustre figura da Rainha dá visibilidade às características dos verdadeiros profissionais de enfermagem, na medida em que ela "... cuida e cura com as próprias mãos as chagas do corpo e da alma fazendo verdadeiros milagres.", indo ao encontro dos mais fracos e desfavorecidos, procurando levar algum alento e consolação, revelando-se uma pioneira na área do cuidar.

Quem lida com a Sr. ${ }^{a}$ Professora Nídia de perto sabe que é assim. De forma subtil toca-nos com a ponta dos dedos e depois vai transmitindo a sua energia ao ponto de nos segurar de forma firme e doce em simultâneo, partilhando o seu calor humano e demonstrando o seu cuidado na relação que connosco estabelece. O estímulo que as suas mãos transmitem promove o nosso desenvolvimento, o incremento de capacidades que podiam estar latentes e não evidentes e que nos permitem interagir com os outros e com o mundo de forma diferente, pautada por sentimentos de compaixão, serenidade, paz, amor e vitalidade. Pelas mãos, é possível falar quando as palavras são parcas, verificando-se que o seu impacto é poderoso e duradouro e facilitador do estabelecimento de uma relação de confiança.

\section{Bibliografia:}

DECRETO-LEI no 37418/49. D.G. I Série. 105 (49-05-18) 351-352.

DECRETO-LEI no 48166/67. D.R. I Série. 299 (67-12-27) 25142516. 
FREITAS, Marília Pais Viterbo (2012) - Vidas de enfermeiras. Loures: Lusociência.

PORTARIA no 34/70. D.G. I Série. 11 (70-01-14) 58-64.

PORTARIA no 674/76. D.R. I Série. 266 (76-11-13) 2586-2588.

PORTARIA no ${ }^{0}$ 14482/53. D.G. I Série. 166 (53-08-03) 1047-1057.

SALGUEIRO, Nídia (1999) - O "cuidar" na obra da Rainha Santa Isabel. Revista de Enfermagem Referência. Série 1, nº 3, p. 81-87.

SALGUEIRO, Nídia (2003) - A enfermagem e os seus ritos iniciáticos. Revista de Enfermagem Referência. Série 1, $n^{0}$ 10, p. 91-96.

SALGUEIRO, Nídia (2004) - Lares de alunas(os) de enfermagem e de enfermeiras(os) de Coimbra - enquadramento histórico social. Revista de Enfermagem Referência. Série 1, no 12, p. 85-95.

SALGUEIRO, Nídia (2006) - O enfermeiro e a responsabilidade de se tornar competente. Jornal Enfermagem e o Cidadão. № 10 , p. 1-3.
SALGUEIRO, Nídia (2007a) - As mãos, ferramenta mágica: manter as mãos limpas e seguras, um dever de cidadania. Jornal Enfermagem e o Cidadão. $N^{\circ} 11$, p. 11-14.

SALGUEIRO, Nídia (2007b) - As mãos, ferramenta mágica: manter as mãos limpas e seguras, um dever de cidadania (continuação). Jornal Enfermagem e o Cidadão. № 12, p. 11-12.

SALGUEIRO, Nídia (2007c) - Mestria das mãos: história de umas mãos que cuidam... Revista de Enfermagem Referência. Série 2, no 5 , p. 93-99.

SALGUEIRO, Nídia (2010) - A antiga Escola de Enfermagem Dr. Ângelo da Fonseca e a Direcção Geral dos Desportos do Centro, na promoção das actividades de natação em Coimbra. Revista de Enfermagem Referência. Série 2, no 12, p. 113-120.

SALGUEIRO, Nídia ; CARVALHO, Amílcar (2007) - Do LAEC à Sede da SRC da Ordem dos Enfermeiros. Coimbra: Ordem dos Enfermeiros, Secção Regional do Centro. 
